\title{
Oxidative DNA damage estimated by urinary 8-hydroxydeoxyguanosine and indoor air pollution among non-smoking office employees
}

\author{
Chung-Yen Lu ${ }^{\mathrm{a}}$, Yee-Chung Ma ${ }^{\mathrm{a}}$, Jia-Min Lin ${ }^{\mathrm{a}, \mathrm{b}}$, Chun-Yu Chuang ${ }^{\mathrm{c}}$, Fung-Chang Sung ${ }^{\mathrm{a}, \mathrm{b}, \mathrm{d}, *}$ \\ ${ }^{a}$ Institute of Environmental Health, National Taiwan University College of Public Health, 17 Xu-Zhou Road, Taipei 100, Taiwan \\ ${ }^{\mathrm{b}}$ Preventive Medicine, National Taiwan University College of Public Health, 17 Xu-Zhou Road, Taipei 100, Taiwan \\ ${ }^{c}$ Institute of Nuclear Science, National Tsing Hua University College of Nuclear Science, 101 Kuang Fu Road Sec. 2, Hsinchu 300, Taiwan \\ ${ }^{\mathrm{d}}$ Institute of Environmental Health, China Medical University College of Public Health, 91 Hsueh-Shih Road, Taichung 404, Taiwan
}

Received 4 April 2006; received in revised form 11 August 2006; accepted 23 August 2006

Available online 10 October 2006

\begin{abstract}
This study investigated whether urinary 8-hydroxydeoxyguanosine (8-OHdG), a biomarker of oxidative stress, was associated with indoor air quality for non-smokers in high-rise building offices. With informed consents, urine samples from 344 non-smoking employees in 86 offices were collected to determine $8-\mathrm{OHdG}$ concentrations. The concentrations of carbon dioxide $\left(\mathrm{CO}_{2}\right)$ and total volatile organic compounds (TVOCs) in each office and outside of the building were simultaneously measured for eight office hours. The average workday difference between indoor and outdoor $\mathrm{CO}_{2}$ concentrations $\left(\mathrm{dCO}_{2}\right)$ was used as a surrogate measure of the ventilation efficiency for each office unit. The $\mathrm{CO}_{2}$ levels in the offices ranged $467-2810$ ppm with a mean of 1170 ppm, or 2.7 times higher than that in the outside air. The average urinary $8-\mathrm{OHdG}$ levels among employees increased from $3.10 \mu \mathrm{g} / \mathrm{g}$ creatinine, for those at the lowest tertile levels of both $\mathrm{dCO}_{2}$ and TVOCs, to $6.27 \mu \mathrm{g} / \mathrm{g}$ creatinine, for those at the highest tertile levels. Multivariate logistic regression analysis showed that the risk of having the urinary $8-\mathrm{OHdG}$ level of greater than the median, $4.53 \mu \mathrm{g} / \mathrm{g}$ creatinine, for participants was increased significantly at the highest tertile $\mathrm{dCO}_{2}$ level of $>680 \mathrm{ppm}$ (odds ratio $(\mathrm{OR})=3.37,95 \%$ confidence interval $(\mathrm{CI})=1.20-9.46$ ). The effect was significant at the middle tertile TVOCs level of $114-360 \mathrm{ppb}(\mathrm{OR}=2.62,95 \% \mathrm{CI}=1.43-4.79)$, but not at the highest tertile. Inadequate ventilation in office increases the risk of building-related oxidative stress in non-smoking employees.
\end{abstract}

(C) 2006 Elsevier Inc. All rights reserved.

Keywords: Oxidative stress; 8-hydroxydeoxyguanosine; Carbon dioxide; Volatile organic compounds; Ventilation rate; High-rise building office

\section{Introduction}

Reactive oxygen species (ROS) in urban air pollutants may conduce to DNA damage (Chuang et al., 2003; Staessen et al., 2001; Vine et al., 2000). In the exposure of ROS, 8-hydroxydeoxyguanosine (8-OHdG) is formed by the action of hydroxyl radicals on the C-8 of guanosine as a marker of repairing damaged DNA (Floyd et al., 1990;

\footnotetext{
*Corresponding author. Institute of Environmental Health, China Medical University College of Public Health, 91 Hsueh-Shih Road, Taichung 404, Taiwan. Fax: +886422019001.

E-mail addresses: fcsung@mail.cmu.edu.tw, , sung@ha.mc.ntu.edu.tw (F.-C. Sung).
}

Fraga et al., 1990; Shigenaga et al., 1989). CalderonGarciduenas et al. (1999) found that 8-OHdG levels in the nasal cavity respiratory track epidermal cells is higher in children living in the urban area, compared to rural areas, and attributed it to air pollution.

Elevated urinary 8-OHdG levels have also been detected in smokers and occupational drivers, due to the formation of oxidative DNA adduct from routine exposure to cigarette smoke and traffic exhaust (Anderson et al., 1991; Chuang et al., 2003; Loft et al., 1992; Samet et al., 1987). Lodovici et al. (2000) found the average of urinary 8 -OHdG concentrations in smokers was 2 -fold higher than that in never smokers. Chuang et al. (2003) found the distribution of urinary $8-\mathrm{OHdG}$ levels in community male 
smokers is similar to that in male never smoking taxi drivers. These findings suggest a considerable contribution of occupational driving to the level of 8-OHdG.

Tobacco smoke may stimulate the activation of the macrophage cells in the human body, leading to oxidative damage in the respiratory track (Anderson et al., 1991; Samet et al., 1987). In addition to chemicals in automobile exhaust and tobacco smoke, volatile organic carbons (VOCs) and ionization radiation can also result in a rise of urinary 8-OHdG levels (Carstensen et al., 1999; Tagesson et al., 1995, 1996; Wilson et al., 1993).

Most of the above studies are related to exposure in industries, traffic and tobacco smoke. To our knowledge, no study has investigated the contribution of indoor air pollution to the urinary 8-OHdG levels for office employees who have less exposure to traffic exhaust and tobacco smoking. This study evaluated the association between the levels of urinary 8-OHdG and indoor air pollution exposure for non-smoking individuals working in high-rise building offices.

\section{Materials and methods}

\subsection{Study subjects and data collection}

From November 2003 through June 2004, we randomly selected 16 government and commercial organizations in eight high-rise buildings with central ventilation system, in Taipei city, Taiwan, for subject recruitment and indoor air pollutants measurement. Five organizations declined to participate. Three of the remaining 11 institutions were excluded from this study because urinary specimens were not available. None of these office buildings previously reported indoor air quality issues. An invitation letter explaining the study was delivered to potential participants in 86 office units in the remaining eight organizations. With informed consent, 398 persons with full time jobs at these offices responded to our invitation (response rate $61.7 \%$ ). Data of smokers were excluded from the present study. Each person was asked to provide a spot urine sample and return a self-reported questionnaire with information on lifestyle, and socioeconomic and health status. Urine samples, collected from participants at the end of the work day, were transported in a cold box of $4{ }^{\circ} \mathrm{C}$ to the laboratory stored at $-80^{\circ} \mathrm{C}$ until analysis. A review committee established at the National Science Council, Taiwan, reviewed and approved this study. We have adhered to the study ethics.

\section{2. $\mathrm{dCO}_{2}$ and TVOCs measurement}

We used portable monitors at each office to simultaneously detect the levels of carbon dioxide $\left(\mathrm{CO}_{2}\right)$ and total volatile organic compounds (TVOCs) to represent indoor air pollution levels. The $\mathrm{CO}_{2}$ measure was standardized against a wide range $(0-5000 \mathrm{ppm})$ of $\mathrm{CO}_{2}$ and delicate resolution (1 ppm) (Q-TRAK IAQ Model 8551, TSI Incorporated, Shoreview, MN, USA). TVOCs measures were standardized against 102 categories of volatile organic compounds (VOCs) with acceptable deviation (20 ppb) (PGM-7240, RAE SYSTEMS, California, USA). During office hours (from 9:00 a.m. to 6:00 p.m.), monitors were placed in the middle of the office, at $1.2 \mathrm{~m}$ height, away from any window or airconditioner. Standard gas calibration was performed prior to each measurement. Eight-hour averaged workday difference between indoor and outdoor $\mathrm{CO}_{2}$ concentrations $\left(\mathrm{dCO}_{2}=\mathrm{CO}_{2}\right.$ indoor $-\mathrm{CO}_{2}$ outdoor $)$ (Apte et al., 2000) was used as a surrogate measure for building occupancy and per-person ventilation in an office.

\subsection{Determinations of urinary creatinie and $8-O H d G$}

Thawed urine samples were pretreated with centrifuge at $3000 \mathrm{~g}$ for $10 \mathrm{~min}$ to remove the particulate matters. The creatinine value in the urine sample was determined with an automatic analyzer (Hitachi 7250, Tokyo, Japan) based on the Jaffe colorimeter reaction (Nerurkar and Sahasrabudhe, 1960).

Urinary 8-OHdG was determined using the OXIS research ${ }^{\mathrm{TM}}$ enzymelinked immunosorbent assay (ELISA) kit (Japan Institute for the Control of Aging, Shizuoka, Japan) with high sensitivity and specificity and easy operation. At room temperature, $50 \mu$ of primary antibody were added to $50 \mu \mathrm{l}$ aliquot of each sample or standard in microtiter plates pre-coated with 8-OHdG for assay, using the procedure developed by Yin et al (1995). The 8-OHdG concentrations in samples were determined by comparing the absorbance values at $450 \mathrm{~nm}$ with a calibration curve generated by $0.5,2,8,20,80$ and $200 \mathrm{ng} / \mathrm{ml} 8-\mathrm{OHdG}$. The results were expressed as $\mu \mathrm{g} / \mathrm{g}$ creatinine.

\subsection{Statistical analysis}

Means \pm standard deviations, medians and ranges for both indoor and outdoor $\mathrm{CO}_{2}$, and TVOCs concentrations were calculated. Student's $t$-test and generalized linear model (GLM) were performed to evaluate the differences of urinary $8-\mathrm{OHdG}$ levels by sex and age, respectively. We further performed comparisons in urinary 8-OHdG levels to determine the interaction between exposures to $\mathrm{CO}_{2}$ and VOCs. Means of urinary 8-OHdG contents were calculated by tertiles of $\mathrm{dCO}_{2}(<390 \mathrm{ppm}$, $390-680 \mathrm{ppm}$ and $>680 \mathrm{ppm})$ and tertiles of TVOCs $(<114 \mathrm{ppb}$, $114-360 \mathrm{ppb}$ and $>360 \mathrm{ppb}$ ). Using the overall median of 8-OHdG levels as the cut-off of elevated concentration, odds ratios (OR) and corresponding $95 \%$ confidence intervals (CI) were calculated using logistic regression analyses to identify factors associated with the elevation of urinary $8-\mathrm{OHdG}$, such as gender, age, working hours per day, using sanitizing chemicals, environmental tobacco smoking (ETS) sensitivity, chemical sensitivity, exposure to ETS, and indoor environmental quality. The overall median $8-\mathrm{OHdG}(4.53 \mu \mathrm{g} / \mathrm{g}$ creatinine) among all study participants was used as the cut-off point of elevated concentration in the logistic regression analysis.

\section{Results}

\subsection{Levels of $\mathrm{dCO}_{2}$ and TVOCs exposure}

Table 1 depicts the statistical distribution of environmental measurements for all 86 offices. The results of 8hour measures of indoor air revealed an hourly average (standard deviation, SD) difference of $\mathrm{CO}_{2} \quad\left(\mathrm{dCO}_{2}\right)$

Table 1

Summary statistics for environmental measurements among high-rise building offices with study participants worked in

\begin{tabular}{lccc}
\hline Index & Mean & S.D. & \multicolumn{1}{l}{ Range } \\
\hline Environmental covariates $(n=86)$ & & & \\
$\mathrm{CO}_{\text {2indoor }}(100 \mathrm{ppm})$ & 11.7 & 6.06 & $4.67-28.1$ \\
$\mathrm{CO}_{\text {2outdoor }}(100 \mathrm{ppm})$ & 4.35 & 0.60 & $3.37-5.63$ \\
Difference $^{\mathrm{a}}$ & 7.36 & 6.29 & $-0.96-23.9$ \\
$\mathrm{TVOC}_{\text {indoor }}(100 \mathrm{ppb})$ & 12.1 & 60.9 & $0.06-557$ \\
TVOC $_{\text {outdoor }}(100 \mathrm{ppb})$ & 1.81 & 1.60 & $0.05-4.25$ \\
Difference $^{\mathrm{a}}$ & 10.3 & 60.5 & $-1.46-553$ \\
Relative humidity, $\mathrm{RH}(\%)_{\text {Temperature, } T\left({ }^{\circ} \mathrm{C}\right)}^{57.6}$ & 7.36 & $45.5-79.7$ \\
& 23.6 & 1.68 & $18.6-28.4$ \\
\hline
\end{tabular}

${ }^{\mathrm{a}}$ Between indoor and outdoor. 
concentrations of 736 (629) ppm, between indoor and outdoor measures, with the range between -96 and $2390 \mathrm{ppm}$. The hourly average (SD) TVOCs concentration was 1210 (6090) ppb with the range between 6 and $55,700 \mathrm{ppb}$ in the offices.

\subsection{Urinary 8-OHdG levels in never smokers}

The daily average (SD) and median time they exposed to the office environments was $8.6(1.4)$ and $9.0 \mathrm{~h}$, respectively, with the range between 3 and $16 \mathrm{~h}$ (data not shown). Most participants were women $(81.4 \%)$ and aged between 30 and 39 years old $(40.1 \%$ ) (Table 2 ). The overall average (SD) urinary $8-O h d G$ in the whole samples was 5.15 (2.86) $\mu \mathrm{g} / \mathrm{g}$ creatinine with a median of $4.53 \mu \mathrm{g} / \mathrm{g}$ creatinine. The average was somewhat greater in men $(5.43 \pm 2.65 \mu \mathrm{g} / \mathrm{g}$ creatinine) than in women $(5.08 \pm 2.91 \mu \mathrm{g} / \mathrm{g}$ creatinine $)$ $(P=0.38)$, and higher in participants of 30-39 years old

Table 2

Averages and ranges of urinary 8-hydroxydeoxyguanosine levels measured for non-smoking office employees by sex and environmental tobacco smoke exposure

\begin{tabular}{lllll}
\hline Variable $(N)$ & \multicolumn{2}{l}{$8-\mathrm{OHdG}^{\mathrm{a}}(\mu \mathrm{g} / \mathrm{g}$ creatinine } & \multirow{2}{*}{$P$-value } \\
\cline { 2 - 4 } & Mean (S.D.) & Median & Range & \\
\hline All (344) & $5.15(2.86)$ & 4.53 & $1.06-16.7$ & \\
Sex & & & & \\
$\quad$ Female (280) & $5.08(2.91)$ & 4.48 & $1.06-16.7$ & $0.38^{\mathrm{c}}$ \\
$\quad$ Male (64) & $5.43(2.65)$ & 4.89 & $1.06-12.1$ & \\
Age & & & & \\
$\quad<30(95)$ & $5.04(2.45)$ & 4.51 & $1.07-12.09$ & $0.43^{\mathrm{d}}$ \\
$30-39(138)$ & $5.44(3.12)$ & 4.84 & $1.08-16.66$ & \\
$\quad 40-49(54)$ & $4.75(2.66)$ & 4.05 & $1.06-11.28$ & \\
$>50(57)$ & $4.99(3.02)$ & 4.95 & $1.06-11.82$ & \\
\hline
\end{tabular}

a 8-hydroxydeoxyguanosine.

${ }^{\mathrm{b}}$ Standard deviation.

${ }^{\mathrm{c}}$ Statistical $t$-test between means.

${ }^{\mathrm{d}}$ Generalized linear model (GLM) between means.
$(5.44 \pm 3.12 \mu \mathrm{g} / \mathrm{g}$ creatinine) than in other age groups $(P=0.43)$.

Table 3 shows mean $8-\mathrm{OHdG}$ levels among never smokers by tertile levels of $\mathrm{dCO}_{2}$ and TVOCs exposure. The mean (SD) values increased from $3.10(1.56) \mu \mathrm{g} / \mathrm{g}$ creatinine at the lowest $\mathrm{dCO}_{2}$ and TVOCs tertile levels to $6.27(3.03) \mu \mathrm{g} / \mathrm{g}$ creatinine at the highest tertile levels.

Further logistic regression analysis revealed that the crude OR for the elevated $8-\mathrm{OHdG}$ level was significantly higher for (1) often use chemicals to sanitize, (2) not sensitive to ETS, (3) not sensitive to chemical, and those with (4) lower temperature (below $23.8^{\circ} \mathrm{C}$ ), (5) lower relative humidity (below $55.8 \%$ ), (6) $\mathrm{dCO}_{2}$ levels at the second tertile level (between 390 and $680 \mathrm{ppm}$ ) and greater, and (7) TVOCs exposure at the second tertile level (between 114 and $360 \mathrm{ppb}$ ) and greater (Table 4). In the multivariate logistic regression analysis, the factors remained a significant association with 8-OhdG were sensitive to ETS, and exposure to $\mathrm{dCO}_{2}$ and TVOCs. The 8-OHdG levels had a significant dose-response relation with $\mathrm{dCO}_{2}$ level $(P=0.03)$. Individuals with the exposure at the highest tertile $\mathrm{dCO}_{2}$ level had an OR of $3.37(95 \%$ $\mathrm{CI}=1.20-9.46)$. However, the association with TVOCs exposure at the highest tertile level became non-significant. Individuals sensitive to ETS were protected from having higher 8-OHdG levels in urine $(\mathrm{OR}=0.53 ; 95 \%$ $\mathrm{CI}=0.29-0.98)$. But, the ETS exposure was not a significant factor in the model.

\section{Discussion}

Occupational exposure to chemicals has been associated with the considerable increase of urinary $8-\mathrm{OHdG}$ concentration, such as engine oil (Nilsson et al., 2004), benzene exposure (Lagorio et al., 1994), styrene and chromium (Kuo et al., 2003; Marczynski et al., 1997), coal-tar-pitch dust and/or asphalt fume (Toraason, 1999) and traffic exhaust (Chuang et al., 2003). Heavy industry exposure

Table 3

Means (and standard deviations) of urinary 8-hydroxydeoxyguanosine ${ }^{\mathrm{a}}$ by tertile levels of $\mathrm{dCO}_{2}{ }^{\mathrm{b}}$ and $\mathrm{TVOCs}^{\mathrm{c}}$ exposure in offices for non-smoking employees $(N=344)$

\begin{tabular}{|c|c|c|c|c|c|}
\hline \multirow[t]{2}{*}{ Exposure index } & \multicolumn{5}{|l|}{$\mathrm{dCO}_{2}, \mathrm{ppm}$} \\
\hline & $<390$ & $390-680$ & $>680$ & Total & $P$-value \\
\hline \multicolumn{6}{|l|}{ TVOCs, ppb } \\
\hline$<114$ & $3.10(1.56)$ & $4.91(2.41)$ & - & $3.96(2.20)$ & $<0.001^{\mathrm{d}}$ \\
\hline $114-360$ & $4.60(2.50)$ & $5.07(2.63)$ & $6.65(2.55)$ & $5.06(2.62)$ & \\
\hline$>360$ & - & $6.67(3.65)$ & $6.27(3.03)$ & $6.34(3.14)$ & \\
\hline $\begin{array}{l}\text { Total } \\
P \text {-value }\end{array}$ & $3.80(2.18)$ & $5.28(2.80)$ & $6.32(2.97)$ & $5.15(2.86)$ & $<0.001^{\mathrm{e}}$ \\
\hline
\end{tabular}

a 8 -hydroxydeoxyguanosine, $\mu \mathrm{g} / \mathrm{g}$ creatinine shown in table field.

${ }^{\mathrm{b}}$ Difference between indoor and outdoor carbon dioxide.

${ }^{\mathrm{c}}$ Indoor total volatile organic compounds.

${ }^{\mathrm{d}}$ Statistical test: analysis of variance.

${ }^{\mathrm{e}} P$ for trend. 
Table 4

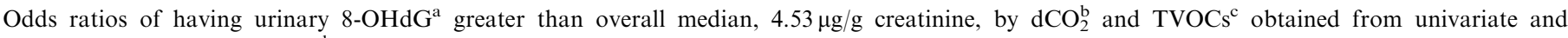
multivariate logistic regression ${ }^{\mathrm{d}}$ for non-smoking office employees $(N=344)$

\begin{tabular}{|c|c|c|c|c|}
\hline & Crude $\mathrm{OR}^{\mathrm{e}}$ & $95 \% \mathrm{CI}$ & Adjusted OR & $95 \% \mathrm{CI}$ \\
\hline \multicolumn{5}{|l|}{ Gender } \\
\hline Female & 1.00 & \multirow{3}{*}{$0.73-2.17$} & 1.00 & \multirow{3}{*}{$0.59-2.01$} \\
\hline Male & 1.26 & & 1.09 & \\
\hline$P$-value & 0.41 & & 0.51 & \\
\hline \multicolumn{5}{|l|}{ Age (year) } \\
\hline$<40$ & 1.00 & \multirow{3}{*}{$0.59-1.45$} & 1.00 & \multirow{3}{*}{$0.61-1.71$} \\
\hline$>40$ & 0.92 & & 1.02 & \\
\hline$P$-value & 0.73 & & 0.73 & \\
\hline \multicolumn{5}{|l|}{ Working hours per day } \\
\hline$<9$ & 1.00 & \multirow{3}{*}{$0.81-1.88$} & 1.00 & \multirow{3}{*}{$0.87-2.28$} \\
\hline$>9$ & 1.23 & & 1.41 & \\
\hline$P$-value & 0.33 & & & \\
\hline \multicolumn{5}{|c|}{ Sanitizing by using chemicals } \\
\hline Never or sometimes & 1.00 & \multirow{3}{*}{$1.11-2.90^{\mathrm{f}}$} & 1.00 & \multirow{3}{*}{$0.75-2.20$} \\
\hline Often & 1.79 & & 1.29 & \\
\hline$P$-value & $0.02^{\mathrm{f}}$ & & 0.12 & \\
\hline \multicolumn{5}{|c|}{ Environmental tobacco smoking sensitivity } \\
\hline No & 1.00 & \multirow{3}{*}{$0.30-0.81^{\mathrm{f}}$} & 1.00 & \multirow{3}{*}{$0.28-0.98^{f}$} \\
\hline Yes & 0.49 & & 0.53 & \\
\hline$P$-value & $0.01^{\mathrm{f}}$ & & 0.07 & \\
\hline \multicolumn{5}{|l|}{ Chemical sensitivity } \\
\hline No & 1.00 & \multirow{3}{*}{$0.32-0.80^{\mathrm{f}}$} & 1.00 & \multirow{3}{*}{$0.45-1.42$} \\
\hline Yes & 0.51 & & 0.80 & \\
\hline$P$-value & $<0.01^{\mathrm{f}}$ & & 0.52 & \\
\hline \multicolumn{5}{|c|}{ Exposure to secondhand smoke } \\
\hline No & 1.00 & \multirow{3}{*}{$0.82-2.51$} & 1.00 & \multirow{3}{*}{$0.69-2.35$} \\
\hline Yes & 1.44 & & 1.27 & \\
\hline$P$-value & 0.21 & & 0.27 & \\
\hline \multicolumn{5}{|l|}{ Room temperature $\left({ }^{\circ} \mathrm{C}\right)$} \\
\hline$<23.8$ & 1.00 & \multirow{3}{*}{$0.31-0.74^{\mathrm{f}}$} & 1.00 & \\
\hline$\geqq 23.8$ & 0.48 & & 0.98 & $0.51-1.87$ \\
\hline$P$ for trend & $<0.01^{\mathrm{f}}$ & & 0.55 & \\
\hline Relative humidity (\%) & & & & \\
\hline$<55.8$ & 1.00 & & 1.00 & \\
\hline$\geqq 55.8$ & 0.57 & $0.37-0.87^{\mathrm{f}}$ & 0.91 & $0.53-1.56$ \\
\hline$P$ for trend & $0.01^{\mathrm{f}}$ & & 0.68 & \\
\hline $\mathrm{dCO}_{2}(\mathrm{ppm})$ & & & & \\
\hline$<390$ & 1.00 & & 1.00 & \\
\hline $390-680$ & 1.94 & $1.13-3.32^{\mathrm{f}}$ & 1.74 & $0.92-3.29$ \\
\hline$\geqq 680$ & 4.83 & $2.75-8.46^{\mathrm{f}}$ & 3.37 & $1.20-9.46^{\mathrm{f}}$ \\
\hline$P$ for trend & $<0.01^{\mathrm{f}}$ & & $0.03^{\mathrm{f}}$ & \\
\hline TVOCs (ppb) & & & & \\
\hline$<114$ & 1.00 & & 1.00 & \\
\hline $114-360$ & 2.68 & $1.54-4.64^{\mathrm{f}}$ & 2.62 & $1.43-4.79^{\mathrm{f}}$ \\
\hline$\geqq 360$ & 4.59 & $2.65-7.96^{\mathrm{f}}$ & 1.94 & $0.79-4.74$ \\
\hline$P$ for trend & $0.05^{\mathrm{f}}$ & & 0.12 & \\
\hline
\end{tabular}

a-hydroxydeoxyguanosine.

${ }^{\mathrm{b}}$ Difference between indoor and outdoor carbon dioxide.

${ }^{\mathrm{c}}$ Indoor total volatile organic compounds.

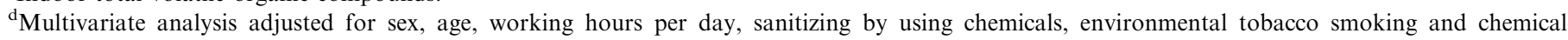
sensitivity, environmental tobacco smoke exposure, temperature, relative humidity, $\mathrm{dCO}_{2}$, and TVOCs.

e Odds ratios.

${ }^{\mathrm{f}}$ Statistically significance $(P<0.05)$.

may confound the contribution of smoking to oxidative DNA stress (Loft and Poulson, 1998; Toraason, 1999). With no industrial chemical exposure, there has been no study investigating factors associated with 8 -OHdG for non-smoking employees in high-rise building offices.
This study used urinary $8-\mathrm{OHdG}$ to represent DNA damage associated with the exposure of indoor air pollution among non-smokers at offices of high-rise buildings. There were wide ranges in the concentrations of both $\mathrm{dCO}_{2}$ and dTVOC (Table 1), reflecting a large 
variation in indoor accumulation of pollutants. The range of $8-\mathrm{OHdG}$ measured was also wide and had significant associations with both $\mathrm{dCO}_{2}$ and dTVOC. Age could influence the excretion of 8-OHdG in human tissues and in urine (Mecocci et al., 1993). However, we did not find this kind of association in the present study (Table 2). Hayakawa et al. (1991) have reported the slowed accumulation of $8-\mathrm{OHdG}$ in mitochondrial DNA of the elderly subjects aged over 65 . Most participants in this study were younger than $50(83.4 \%)$ and the effect of age-associated accumulation of $8-\mathrm{OHdG}$ in human DNA was not observed. Kimura et al. (2006) also reported the mean concentrations of $8-\mathrm{OHdG}$ in urine were not significantly different between age groups ( $<45$ vs. $\geqslant 45$ years) and between males and females for healthy Japanese people. The oxidative damage occurs rapidly after exposure, and this damage can be repaired rapidly (Wong, et al., 2005). The oxidative DNA damage is expected to be associated with the exposure time (i.e., hours at the offices). The multivariate analysis shows that participants working for longer than $9 \mathrm{~h}$ had higher urinary 8 -OHdG than those working for fewer hours; but the difference was not significant. This is because the indoor air pollution levels vary among offices and the contribution of exposure time may become less significant.

The measured urinary 8-OHdG values in this study may exclude most the effects from both traffic exhaust and tobacco smoke. The levels of $\mathrm{dCO}_{2}$ and TVOCs measured in the offices represented indoor pollution the study participants exposed to. Their average (SD) urinary 8-OHdG level of $5.15(2.86) \mu \mathrm{g} / \mathrm{g}$ creatinine, indicating a substantial DNA damage was due to oxidative stress from indoor pollution instead of the exposure to chemicals in traffic exhaust and tobacco smoke.

An earlier study in the same city found that the average (SD) urinary 8-OHdG values were $12.2(3.4) \mu \mathrm{g} / \mathrm{g}$ creatinine in non-smoking taxi drivers associated with traffic exhaust exposure and $13.3(4.5) \mu \mathrm{g} / \mathrm{g}$ creatinine in community men associated with smoking (Chuang et al., 2003). Lai, et al. (2005) reported a similar average level, 13.3 (7.1) $\mu \mathrm{g} / \mathrm{g}$ creatinine of urinary $8-\mathrm{OHdG}$ for highway toll station workers. Zagury et al. (2000) also reported a higher black smoke exposure for taxi drivers in Paris. It is not possible to affirm that at the largest levels of $8-\mathrm{OHdG}$ is due to the oxidative stress induced by environmental exposure. Air pollution contains a large amount of free radicals. Although cells have developed various enzymatic and non enzymatic systems to control excited oxygen species such as the superoxide radical $\left(\mathrm{O}^{2-}\right)$, singlet oxygen $\left({ }^{\circ} \mathrm{O}\right)$, hydrogen peroxide $\left(\mathrm{H}_{2} \mathrm{O}_{2}\right)$ and hydroxyl radicals $\left({ }^{\circ} \mathrm{OH}\right)$, excessive generation of them within tissues may damage proteins, lipids and nucleic acids (Yin et al., 1995).

The excretion of urinary 8-OHdG has been correlated with ETS exposure (Loft and Poulsen, 1996). In the present study, participants who were sensitive to ETS might have avoided the exposure. Therefore, we failed to find a significant association between ETS and the urinary
8-OHdG levels. Smith et al. (2001) also reported that nonsmokers exposed to ETS for at least five hour per day do not have significantly increased $8-\mathrm{OHdG}$ levels.

Carbon dioxide, tobacco smoking, secondhand smoke, temperature, dampness and VOC have been noticed in sick building syndrome (SBS) etiologic studies (Bako-Biro et al., 2004; Engvall et al., 2001; Kim et al., 2002; Lyles et al., 1991; Norback and Edling, 1991; Pommer et al., 2004; Sari et al., 2004; Skov et al., 1989). $\mathrm{CO}_{2}$ is thought to be the major factor associated with SBS symptoms (Apte et al., 2000; Backman and Haghighat, 1999; Bourbeau et al., 1997; Seppänen et al., 1999). It is understood that there is no direct causal link between exposure to $\mathrm{CO}_{2}$ and SBS symptoms, but rather $\mathrm{CO}_{2}$ is approximately correlated with other indoor pollutants that may cause symptoms. We also suspect $\mathrm{CO}_{2}$ of having association with DNA damage effect as shown in the 8-OHdG relationship. It is likely that this association is from other factors correlated with $\mathrm{CO}_{2}$, in addition to TVOCs.

The primary source of indoor $\mathrm{CO}_{2}$ for office buildings is generated from the respiratory of employees and bioeffluents, varied with the ventilation rate in the office (ACGIH, 1991; ASHRAE, 2001). Higher indoor $\mathrm{CO}_{2}$ concentration reflects lower per occupant ventilation rate, with less fresh air supply to the rooms. The difference between indoor and outdoor $\mathrm{CO}_{2}$ concentrations can be used as a surrogate measure for building ventilation in an office (Apte et al., 2000). Inefficient ventilation increases indoor air pollution, such as TVOCs.

In this study, the average indoor $\mathrm{CO}_{2}$ and TVOCs concentrations at the offices were 2.6 and 6.7 times, respectively, higher than those in the air outside the buildings. The concentrations were with a large variation among offices, with ranges from 0.8 to 6.8 times for $\mathrm{CO}_{2}$ and from 0.5 to 131.3 times for TVOCs. With no consideration of the effect of TVOCs of higher levels, the average (SD) urinary $8-\mathrm{OHdG}$ was $3.80 \quad(2.18) \mu \mathrm{g} / \mathrm{g}$ creatinine for persons at the offices with the $\mathrm{dCO}_{2}$ levels at the lowest tertile range. On the other hand, the VOCs are also common indoor air pollutants have been observed in the previous studies (Brasche et al., 2004; Pejtersen et al., 2001; Pitten et al., 2000; Takigawa et al., 2004). The TVOCs have significant associations with skin hydration for the level of higher than $666 \mu \mathrm{g} / \mathrm{m}^{3}$ (289 ppb) (Brasche et al., 2004), and with sore throat, irritations of mucous membrane, headache, and weariness for the level of higher than $990 \mu \mathrm{g} / \mathrm{m}^{3}$ (391 ppb) (Pitten et al., 2000). Some other studies have reported the TVOCs levels in copy centers ranging from $<71$ to $21,300 \mathrm{ppb}$ (Stefaniak et al., 2000).

In this study, the TVOCs levels in offices with the lowest tertile ranging from 6 to $114 \mathrm{ppb}$, were somewhat lower than the average outdoor level of $181 \mathrm{ppb}$. At this tertile interval, the mean (SD) 8 -OHdG was $3.96(2.20) \mu \mathrm{g} / \mathrm{g}$ creatinine with no consideration of the effect of $\mathrm{dCO}_{2}$ of higher levels. The mean (SD) urinary $8-\mathrm{OHdG}$ of 3.10 (1.56) $\mu \mathrm{g} / \mathrm{g}$ creatinine in the lowest tertiles of $\mathrm{dCO}_{2}$ and TVOCs may represent the back ground level effect with no 
effect from additional indoor air pollutants. The increase of mean urinary 8-OHdG was on a parallel with the increase of $\mathrm{dCO}_{2}$ and indoor TVOCs as shown in Table 3. The strong dose-response relationship between average urinary 8-OHdG levels and tertile levels of $\mathrm{dCO}_{2}$ and TVOCs demonstrated a significant interaction relationship between $\mathrm{dCO}_{2}$ level and TVOCs exposure.

To our knowledge, this is the first study on how the urinary $8-\mathrm{OHdG}$ levels are associated with the ventilation status at office. It is interesting to note in the univariate logistic regression analysis that both $\mathrm{dCO}_{2}$ and TVOCs were significantly associated with elevated $8-\mathrm{OHdG}$ levels. But, in the multivariate analysis, the association with TVOCs is less strong than with $\mathrm{dCO}_{2}$. Individuals who are sensitive to ETS may take action to avoid exposing to the secondhand smoke and protected from the oxidative stress for $47 \%$. The $\mathrm{dCO}_{2}$ levels remained as independent predictors of the elevated $8-\mathrm{OHdG}$ levels with a significant dose-response relationship. We hypothesize that the relationship between per person ventilation rate (as traced by $\mathrm{dCO}_{2}$ ) and oxidative stress in office employees is biological credible.

In conclusion, this study found significant association between urinary $8-\mathrm{OHdG}$ and the exposure to $\mathrm{CO}_{2}$ and TVOCs in the office. The dose-response association with $\mathrm{dCO}_{2}$ is of particularly interesting. This association reflects the effect of ventilation efficiency in each office. The VOC exposure could not explain all urinary $8-\mathrm{OHdG}$ measured. Other components deserve further investigation. This association cannot be dismissed and may indicate potential to reduce oxidative stress of employees at work through large increase in ventilation rates.

\section{Acknowledgments}

This work was supported by the National Science Council, Taiwan (NSC 92-2320-B-039-054, 2003-2005). The authors also gratefully acknowledged all the participants in this study.

\section{References}

ACGIH, 1991H. Documentation of the Threshold Limit Values and Biological Exposure Indices, sixth ed. American Conference of Governmental Industrial Hygienists (ACGIH), Cincinnati, OH.

Anderson, R., Theron, A.J., Richards, G.A., Myer, M.S., Van Rensburg, A.J., 1991. Passive smoking by human sensitizers circulating neutrophils. Am. Rev. Respir. 144, 570-574.

Apte, M.G., Fisk, W.J., Daisey, J.M., 2000. Associations between indoor $\mathrm{CO}_{2}$ concentrations and sick building syndromes in U.S. office buildings: an analysis of the 1994-1996 BASE study data. Indoor Air 10, 246-247.

ASHRAE, 2001E. Ventilation for Acceptable Indoor Air Quality (ASHRAE Standard 62-2001). American Society of Heating, Refrigerating and Air-Conditioning Engineers (ASHRAE), Atlanta, USA.

Backman, H., Haghighat, F., 1999. Indoor-air quality and ocular discomfort. Am. Optom. Assoc. 70, 309-316.

Bako-Biro, Z., Wargocki, P., Weschler, C.J., Fanger, P.O., 2004. Effects of pollution from personal computers on perceived air quality, SBS symptoms and productivity in offices. Indoor Air 14, 178-187.
Bourbeau, J., Brisson, C., Allaire, S., 1997. Prevalence of the sick building syndrome symptoms in office workers before and six months and three years after being exposed to a building with an improved ventilation system. Occup. Environ. Med. 54, 49-53.

Brasche, S., Bullinger, M., Schwab, R., Gebhardt, H., Herzog, V., Bischof, W., 2004. Comparison of risk factor profiles concerning self-reported skin complaints and objectively determined skin symptoms in German office workers. Indoor Air 14, 137-143.

Calderon-Garciduenas, L., Wen-Wang, L., Zhang, Y.J., RodriguezAlcaraz, A., Osnaya, N., Villarreal-Calderon, A., Santella, R.M., 1999. 8-hydroxy-2'-deoxyguanosine, a major mutagenic oxidative DNA lesion, and DNA strand breaks in nasal respiratory epithelium of children exposed to urban pollution. Environ. Health Perspect. 107, 469-474.

Carstensen, U., Hou, S.M., Alexandrie, A.K., Hogstedt, B., Tagesson, C., Warholm, M., Rannug, A., Lambert, B., Axmon, A., Hagmar, L., 1999. Influence of genetic polymorphisms of biotransformation enzymes on gene mutations, strand breaks of deoxyribonucleic acid, and micronuclei in mononuclear blood cells and urinary 8-hydroxydeoxyguanosine in potroom workers exposed to polyaromatic hydrocarbons. Scand. J. Work Environ. Health 25, 351-360.

Chuang, C.Y., Lee, C.C., Chang, Y.K., Sung, F.C., 2003. Oxidative DNA damage estimated by urinary 8-hydroxydeoxyguanosine: influence of taxi driving, smoking and areca chewing. Chemosphere 52, 1163-1171.

Engvall, K., Norrby, C., Norbäck, D., 2001. Sick building syndrome in relation to building dampness in multi-family residential buildings in Stockholm. Int. Arch. Occup. Environ. Health 74, 270-278.

Floyd, R.A., West, M.S., Eneff, K.L., Schneider, J.E., 1990. Mediation of 8-hydroxy-guanine formation in DNA by thiazin dyes plus light. Free Radic. Biol. Med. 8, 327-330.

Fraga, C.G., Shigenaga, M.K., Park, J.W., Degan, P., Ames, B.N., 1990. Oxidative damage to DNA during aging: 8-hydroxy-2'-deoxyguanosine in rat organ DNA and urine. Proc. Natl Acad. Sci. USA 87, 4533-4537.

Hayakawa, M., Torii, K., Sugiyama, S., Tanaka, M., Ozawa, T., 1991. Age-associated accumulation of 8-hydroxydeoxyguanosine in mitochondrial DNA of human diaphragm. Biochem. Biophys. Res. Commun. 179, 1023-1029.

Kim, W.J., Terada, N., Nomura, T., Takahashi, R., Lee, S.D., Park, J.H., Konno, A., 2002. Effect of formaldehyde on the expression of adhesion molecules in nasal microvascular endothelial cells: the role of formaldehyde in the pathogenesis of sick building syndrome. Clin. Exp. Allergy 32, 287-295.

Kimura, S., Yamauchi, H., Hibino, Y., Iwamoto, M., Sera, K., Oqino, K., 2006. Evaluation of urinary 8-hydroxydeoxyguanosine in healthy Japanese people. Basic Clin. Pharmacol. Toxicol. 98, 496-502.

Kuo, H.W., Chang, S.F., Wu, F.Y., 2003. Chromium (VI) induced oxidative damage to DNA: increase of urinary 8-hydroxydeoxyguanosine concentrations (8-OHdG) among electroplating workers. Occup. Environ. Med. 60, 590-594.

Lagorio, S., Tagesson, C., Forastiere, F., Iavarone, I., Axelson, O., Carere, A., 1994. Exposure to benzene and urinary concentrations of 8-hydroxydeoxyguanosine, a biological marker of oxidative damage to DNA. Occup. Environ. Med. 51, 739-743.

Lai, C.H., Liou, S.H., Lin, H.C., Shih, T.S., Tsai, P.J., Chen, J.S., Yang, T., Jaakkola, J.J.K., Strickland, P.T., 2005. Exposure to traffic exhausts and oxidative DNA damage. Occup. Environ. Med. 62, 216-222.

Lodovici, M., Casalini, C., Cariaggi, R., Michelucci, L., Dolara, P., 2000. Levels of 8-hydroxydeoxyguanosine as a marker of DNA damage in human leukocytes. Free Radic. Biol. Med. 28, 13-17.

Loft, S., Vistisen, K., Ewertz, M., Tjonneland, A., Overvad, K., Poulsen, H.E., 1992. Oxidative DNA damage estimated by 8-hydroxydeoxyguanosine excretion in humans: influence of smoking, gender and body mass index. Carcinogenesis 13, 2241-2247.

Loft, S., Poulsen, H.E., 1996. Cancer risk and oxidative DNA damage in man. J. Mol. Med. 74, 297-312. 
Loft, S., Poulson, H.E., 1998. Estimation of oxidative DNA damage in man from urinary excretion of repair products. Acta Biochim. Polin. 45, 133-144.

Lyles, W.B., Greve, K.W., Bauer, R.M., Ware, M.R., Schramke, C.J., Crouch, J., Hicks, A., 1991. Sick building syndrome. South Med. J. 84, $65-71$.

Marczynski, B., Rozynek, P., Elliehausen, H.J., Korn, M., Baur, X., 1997. Detection of 8-hydroxydeoxyguanosine, a marker of oxidative DNA damage, in white blood cells of workers occupationally exposed to styrene. Arch. Toxicol. 71, 496-500.

Mecocci, P., MacGarvey, U., Kaufman, A.E., Koontz, D., Shoffner, J.M., Wallace, D.C., Beal, M.F., 1993. Oxidative damage to mitochondrial DNA shows marked age-dependent increases in human brain. Ann. Neurol. 34, 609-616.

Nerurkar, M.K., Sahasrabudhe, M.B., 1960. Synthesis of Creatine in Xirradiated Rats. Int. J. Radiat. Biol. 2, 237-246.

Nilsson, R., Nordlinder, R., Moen, B.E., Ovrebo, S., Bleie, K., Skorve, A.H., Hollund, B.E., Tagesson, C., 2004. Increased urinary excretion of 8-hydroxydeoxyguanosine in engine room personnel exposed to polycyclic aromatic hydrocarbons. Occup. Environ. Med. 61, 692-696.

Norback, D., Edling, C., 1991. Environmental, occupational, and personal factors related to the prevalence of sick building syndrome in the general population. Br. J. Ind. Med. 48, 451-462.

Pejtersen, J., Brohus, H., Hyldgaard, C.E., Nielsen, J.B., Valbjorn, O., Hauschildt, P., Kjaergaard, S.K., Wolkoff, P., 2001. Effect of renovating an office building on occupants' comfort and health. Indoor Air 11, 10-25.

Pitten, F.A., Bremer, J., Kramer, A., 2000. Air pollution by volatile organic compounds (VOC) and health complaints. Dtsch. Med. Wochenschr. 125, 545-550.

Pommer, L., Fick, J., Andersson, B., Sundell, J., Nilsson, C., Sjöström, M., Stenberg, B., 2004. Class separation of buildings with high and low prevalence of SBS by principal component analysis. Indoor Air 14, $16-23$.

Samet, J.M., Marbury, M.C., Spingler, J.D., 1987. Respiratory effect of indoor air pollution. J. Allergy Clin. Immunol. 79, 685-700.

Sari, D.K., Kuwahara, S., Tsukamoto, Y., Hori, H., Kunugita, N., Arashidani, K., Fujimaki, H., Sasaki, F., 2004. Effect of prolonged exposure to low concentrations of formaldehyde on the corticotropin releasing hormone neurons in the hypothalamus and adrenocorticotropic hormone cells in the pituitary gland in female mice. Brain Res. 1013, 107-116.

Seppänen, O.A., Fisk, W.J., Merdell, M.J., 1999. Association of ventilation rates and $\mathrm{CO}_{2}$ concentrations with health and other responses in commercial and institutional buildings. Indoor Air 9, 226-252.

Shigenaga, M.K., Gimeno, C.J., Ames, B.N., 1989. Urinary 8-hydroxy-2'deoxyguanosine as a biological marker of in vivo oxidative DNA damage. Proc. Natl. Acad. Sci. USA 86, 9697-9701.
Skov, P., Valbjørn, O., Pedersen, B.V., 1989. Influence of personal characteristics, job-related factors and psychosocial factors on the sick building syndrome. Scand. J. Work Environ. Health 15, 286-295.

Smith, C.J., Fischer, T.H., Heavner, D.L., Rumple, M.A., Bowman, D.L., Brown, B.G., Morton, M.J., Doolittle, D.J., 2001. Urinary thromboxane, prostacyclin, cortisol, and 8-hydroxy-2'-deoxyguanosine in nonsmokers exposed and not exposed to environmental tobacco smoke. Toxicol. Sci. 59, 316-323.

Staessen, J.A., Nawrot, T., Hond, E.D., Thijs, L., Fagard, R., Hoppenbrouwers, K., Koppen, G., Nelen, V., Sshoeters, G., Vanderschueren, D., Van, H.E., Verschaeve, L., Vlietinck, R., Roels, H., 2001. Renal function, cytogenetic measurements, and sexual development in adolescents in relation to environmental pollutants: a feasibility study of biomarkers. Lancet 357, 1660-1669.

Stefaniak, A.B., Breysse, P.N., Murray, M.P., Rooney, B.C., Schaefer, J., 2000. An evaluation of employee exposure to volatile organic compounds in three photocopy centers. Environ. Res. 83, 162-173.

Tagesson, C., Kallberg, M., Klintenberg, C., Starkhammar, H., 1995. Determination of urinary 8-hydroxydeoxyguanosine by automated coupled-column high performance liquid chromatography: a powerful technique for assaying in vivo oxidative DNA damage in cancer patients. Eur. J. Cancer 31A, 934-940.

Tagesson, C., Kallberg, M., Wingren, G., 1996. Urinary malodialdehyde and 8-hydroxydeoxyguanosine as potential markers of oxidative stress in industrial art glass workers. Int. Arch. Occup. Environ. Health 69, $5-13$.

Takigawa, T., Horike, T., Ohashi, Y., Kataoka, H., Wang, D.H., Kira, S., 2004. Were volatile organic compounds the inducing factors for subjective symptoms of employees working in newly constructed hospital. Environ. Toxic 19, 280-290.

Toraason, M., 1999. 8-Hydroxydeoxyguanosine as a biomarker of workplace exposures. Biomarkers 4, 3-26.

Vine, M.F., Stein, L., Weigle, K., Schroeder, J., Degnan, D., Tse, C.K., Hanchette, C., Backer, L., 2000. Effects on the immune system associated with living near a pesticide dumpsite. Environ. Health Perspect. 108, 1113-1124.

Wilson, V.L., Taffe, B.G., Shields, P.G., Povey, A.C., Harris, C.C., 1993. Detection and quantification of 8-hydroxydeoxyguanosine adducts in periphera; blood of people exposed to ionizing radiation. Environ. Health Perspect. 99, 261-263.

Wong, R.H., Kuo, C.Y., Hsu, M.L., Wang, T.Y., Chang, P.I., Wu, T.H., Huang, S., 2005. Increased levels of 8-hydroxy-2'-deoxyguanosine attributable to carcinogenic metal exposure among school children. Environ. Health Perspect. 113, 1386-1390.

Yin, B., Whyatt, R.M., Perera, F.P., Randall, M.C., Cooper, T.B., Santella, R.M., 1995. Determination of 8-hydroxydeoxyguanosine by an immunoaffinity chromatography-monoclonal antibody-based ELISA. Free Radic. Biol. Med. 18, 1023-1032.

Zagury, E., Moullec, Y.L., Momas, I., 2000. Exposure of Paris taxi drivers to automobile air pollutants within their vehicles. Occup. Environ. Med. 57, 406-410. 